\title{
BUREAUCRACY IN THE UNITED STATES OF AMERICA: A Review of Corporate Policies in the Period of Governance Donald Trump
}

\author{
Ana Sabhana Azmy \\ Universitas Islam Negeri Syarif Hidayatullah Jakarta \\ Jl.Kertamukti No.5, Pisangan, Ciputat, South Tangerang, Banten, Indonesia \\ Correspondence Email: anashabana.azmi@uinjkt.ac.id
}

Submitted: 02-07-2020, Reviewed:20-09-2020, Accepted: 30-10-2020

\begin{abstract}
One of the policies for corporations that reap the pros and cons of Donald Trump's administration is the Tax Reform Act, known as the Tax Cuts and Jobs Act (TCJA)2018. Important points of the Act are: 1) changing the Corporate Income Tax rates from $35 \%$ to $21 \%$ and a drastic reduction that gives tax discounts of up to $60 \%$. 2) change from worldwide to a territorial system. The tax reform was carried out because Trump saw the US tax system was no longer competitive. After all, it had a high corporate income tax rate of 35\% and adopted a worldwide tax system. Pros and cons in discussing this law are that the outcome of the political process contained in the Act is not the same as the initial points put forward by Trump. Using literature studies from various libraries, this paper reviews the characteristics of the bureaucracy in the United States, by looking at the phenomenon of policies issued to corporations during Donald Trump's administration. This paper concludes that the characteristics of bureaucracy in the US tend to dominate institutions; the level of importance is different for each stage. Bureaucracy is seen as an instrument of power for the elite in running the government.
\end{abstract}

Keywords: bureaucracy, government's policy, united states of America

\begin{abstract}
ABSTRAK
Salah satu kebijakan untuk korporasi yang menuai pro dan kontra pada masa Pemerintahan Donald Trump adalah UU Reformasi Pajak atau yang dikenal dengan Tax Cuts and Jobs Act (TCJA), yang berlaku efektif sejak 2018. Point penting UU tersebut adalah: 1) mengubah tarif $\mathrm{PPh}$ Badan dari 35\% ke $21 \%$ dan penurunan drastis yang memberi diskon pajak hingga $60 \%$. 2) perubahan dari sistem worldwide ke territorial. Reformasi pajak dilakukan karena Trump melihat sistem pajak AS sudah tidak kompetitif karena memiliki tarif $\mathrm{PPh}$ Badan yang termasuk tinggi yaitu 35\% dan menganut worldwide tax system. Pro kontra dalam pembahasan UU ini adalah bahwa hasil akhir proses politik yang ada dalam UU tersebut tidak sama dengan pokok-pokok awal yang diajukan Trump. Dengan menggunaka $n$ studi literatur dari berbagai pustaka, tulisan ini mengulas karakteristik birokrasi yang ada di Amerika Serikat, dengan melihat pada fenomena kebijakan yang dikeluarkan untuk korporasi di masa pemerintahan Donald Trump. Kesimpulan dari tulisan ini adalah bahwa karakteristik birokrasi di AS cenderung pada dominasi institusi, yang tingkat kepentingannya berbeda untuk masing-masing tahap. Birokrasi dilihat sebagai alat kekuasaan bagi elit dalam menjalankan pemerintahan.
\end{abstract}

Kata Kunci: birokrasi, kebijakan pemerintah, amerika serikat

\section{BACKGROUND}

By quoting Weber's explanation that bureaucracy is an unavoidable process (Albrow, 2005), it makes bureaucratic discussions in each country interesting because it has superior characteristics. For example, based on Ripley and Franklin's observations made on the bureaucracy in 
Vol.6, No.2, 2020

Doi: https://doi.org/10.24198/cosmogov.v6i2.28428

http://jurnal.unpad.ac.id/cosmogov/index

the United States, there are six characteristics of bureaucracy found; 1) wherever the bureaucracy is located, it is chosen as a social instrument aimed at dealing with problems defined as public affairs. 2) the bureaucracy is the dominant institution in implementing policy programs, which have different levels of importance for each stage. 3) the bureaucracy has some different goals. 4) the function of the bureaucracy is in a broad and complex environment. 5) bureaucracy rarely dies; the survival instinct is unquestionable. 6) the bureaucracy is not something neutral in their policy choices. (Winarno, 2008)

The handling of a problem that can be resolved through the bureaucracy did not escape Max Weber's view. He believed that administration, in general, and the modern state could exert as many influences as the economy is running. Unlike Karl Marx, who explained that society's activities are fundamentally based on the mode of production and economic institutions, Weber believes that authority or domination is the centre of modern society. He also believes that society is indeed alienated, but it is more from an administrative side than material production. (Orum, 2001)

In Weber's view, the state is the highest authority because it has power and power. In a sense, Weber asserts that the modern world occupies an equally important and central place, as the church did in the medieval world. Hence, Weber wrote two criticisms on the organizational dimension of the state. First; the state bureaucracy itself. Based on his observations, that the bureaucracy is central to state organization and administration. $\mathrm{He}$ saw that although the parliament, the congress is parts representing officially elected people, the state bureaucracy also presents state servants (PNS). He pointed out that in 19th century Germany, in fact, the state bureaucracy was more powerful than the elected officials. Second; is the power dimension possessed by certain groups of officials who have privileges over others. An example is a lawyer who understands the law, representing a strong social alliance as society develops more modernly. (Orum, 2001)

Although a democratic state allows for an efficient and transparent bureaucracy because it has aspects of freedom, equality, justice, and fulfilment of citizens' rights, the fact is not the case. Quoting Millib's explanation and when in 1962 he compiled the book "The State in a Capitalist Society", he challenged the hegemony of pluralist political theory. This theory explains that power in Western society is competitive, fragmented and diffuse. Milliband also challenged Key Asian post-war economic theory which states that public policy is autonomous from capitalist interests. Miliband also explains that "the most important fact about advanced capitalist society ... is the continuation of the existence of private and more concentrated economic forces in it." (Milliband, 1973) Thus, he wanted to state that the bureaucracy cannot be neutral. The bureaucracy can become a ruler because it has its own interests, as found in the US bureaucracy's characteristics discussed at the beginning of the paper.

One of the bureaucratic portraits that can be seen in the United States as a 
Vol.6, No.2, 2020

Doi: https://doi.org/10.24198/cosmogov.v6i2.28428

http://jurnal.unpad.ac.id/cosmogov/index

superpower that carries liberalism is corporations' existence. Corporations were born as the US economy grew and impacted significant changes in the business world. A corporation is a form of business organization in the form of a legal entity. The corporation may own its property, sue or be sued in court, and make contracts. Because they are legal entities, the corporations are also taxed by the government. Corporate make the sale and purchase of the property, signed a contract with, and lends money or capital. Corporations first appeared in the railroad industry and later appeared in other endeavours. Sone of the corporate types are most commonly used in the US is a holding company. (Armiyati, 2019)

These corporations have an influence on the Wall Street stock index in the United States. For example, index Dow Jones Industrial Average (DJA), which rose 5.27 becomes 17781.01. The increase in Covidien shares which rose 20 per cent as the world's leading health product, was triggered by plans from a drug technology company in the United States. (Gideon, 2014) Apart from corporations, other things such as government policies on war, domestic policies related to economy and politics, socio-culture, also influence Wall Street.

The name Wall Street is familiar to the financial world around the world. The name Wall Street itself is a street name on the outskirts of Manhattan, New York, starting from the east, namely Broadway down the valley towards South Street on the East River, and passing through the American financial district's historical centre, Manhattan. However, this line is not an ordinary route because a Wall Street building is the first permanent building of the New York Stock Exchange (NYSE). There are many stock exchanges and other trades headquartered on Wall Street and the financial district including the NYSE, NASDAQ, AMEX, NYMEX and NYBOT.

Hence, Wall Street is a place where financial transactions worth billions of US dollars take place every day. For this reason, Wall Street is called the world's financial centre. Based on available information, Wall Street largely determines humans' fate and hundreds of large companies in the world. In fact, US economic indicators can be read on Wall Street. If the stock index on Wall Street falls, it means that something is wrong in the US economy. Conversely, if the index rises, then the US economy is triumphant. Not only that, Wall Street itself has an influence on regional exchanges and developing countries such as the Indonesian Economic Exchange (IDX). (Wdi, 2011)

\section{METHOD}

This paper tries to review the characteristics of the United States bureaucracy by looking at the phenomenon of policies issued to corporations during the Donald Trump administration. To answer this review's focus, this research was conducted through thought-provoking literature research/literature studies related to the bureaucracy in the United States, which focuses on corporate policy studies. The research using secondary data types or data obtained from the literature. Thus, the data collection method is carried out by 
Vol.6, No.2, 2020

Doi: https://doi.org/10.24198/cosmogov.v6i2.28428

http://jurnal.unpad.ac.id/cosmogov/index

searching for relevant literature, both from books, journals, websites and other supporting documents.

In future research relevant to this theme, the author's method will be complemented and refined by conducting interviews with several elements that are part/representatives of the US government in Indonesia such as the Embassy, to inquire about the corporate policies.

\section{RESULT AND DISCUSSION} Portrait of Policy

\section{towards Corporations in the AS}

The modern bureaucracy of the United States has not escaped debates about the nature, authenticity, and significance of the constitution. Much of administrative history marked the 1880 s as the decade when an administrative state was born. In particular, many of the twocredit decisions were: the passing of the Pendleton Act in 1883 and the Interstate Trade Act's passage in 1887. The former established a system of competitive vetting rather than patronage appointments to fill federal offices. The latter created the first federal regulatory commission, the Interstate Trade Commission. In the first step, though hesitant, the scientific story unfolds, America sets itself on the path to an administrative state. (Postell, 2017) Significantly, the original law provisions, which limited the President's power to remove administrative officials, were violated from the last law after constitutional objections were raised. (Postell, 2017)

Bureaucracy, as public administration, as stated by Albrow, is an administrative system, which allocates goods and services in a government, through state policies, and the bureaucracy as the implementer. In this case, the US's policies towards corporations in the US are part of the bureaucratic portrait. The portrait of economic policies that occurred during the Trump administration can be seen from many events. One of them is the trade war between the US and China. Trump responded to the trade war by making a protection policy from imported Chinese goods, which costs up to the US \$ 50 billion. The US economic sector's protection policy has actually been seen when Trump conducted a presidential candidate campaign. The large import tariffs addressed to Chinese products entering the US improve the domestic economy and reduce the trade balance deficit between the two countries. Apart from imposing import tariffs, the US also plans to limit investment and take action for China in the World Trade Organization (WTO) because it considers China unfair in bilateral trade.

This policy direction led to a polemic that occurred in the US itself. However, it can be said that the original intention of this policy was to protect the US economy. Some politicians and industrial circles worry about the possibility of retaliation from China and then affect the life of US agriculture, which has so far depended on exports to China. They are also worried that China will boycott US products that are sent to the ginseng country. The negative reactions from market players eventually affected the US stock market, which experienced a decline. As written by Adirini, Trump's policy is a blow to the "Made in China 2025" policy. 
Vol.6, No.2, 2020

Doi: https://doi.org/10.24198/cosmogov.v6i2.28428

http://jurnal.unpad.ac.id/cosmogov/index

This is the Chinese government's policy to direct the Chinese industry towards innovative industries based on science and technology. (DPR, 2018).

The policy towards corporations in the US regarding taxation issued by Trump also reflects the bureaucracy's portrait as a power exercised by officials, as in one of the points put forward by Albrow. Changes in the US taxation scheme are said to increase the excitement of Uncle Sam's country's business life. However, for many international companies, Donald Trump's policy changes can actually cost companies billions of rupiah in losses. Banks such as Barclays, Credit Suisse and the oil company Shell said that the new taxation was doing them a disservice.

According to them, the losses experienced could reach the US \$ 3 billion or Rp. 40.5 trillion. Previously, Trump passed the Tax Reform Act in December 2017 and is the largest tax reform since the 1980s. (DPR, 2018) Trump explained in his statement that the tax reform law was intended so that the US middle class and small entrepreneurs could exist. The US government also almost doubled the amount of taxes on US citizens. The US government under Donald Trump's leadership has also cut taxes on businesses from 35 per cent to 21 per cent, and with that, Trump hopes US companies can compete in the world. (Setiawan, 2018)

Tax reform policy cannot be separated from Trump's main agenda during the last Presidential Candidate campaign. By carrying the motto "Make America Great Again", Trump can attract many people in the US. Indeed, the US condition at that time was experiencing a very worrying economic situation. In addition to the relatively high number of unemployed people, the trade balance deficit and government debt are getting bigger. The tax reform was carried out because Trump saw that the US tax system was no longer competitive. After all, it had a high corporate income tax rate of $35 \%$ and adhered to the worldwide tax system. (Kristiaji, nd) ${ }^{1}$

Finally, on 22 December 2017, a new law called the Tax Cuts and Jobs Act (TCJA) was passed, effectively enforced in 2018. The media informed that the final results of the political process contained in TCJA were not the same as the initial points stated. Proposed by Trump. However, it can be said that most of Trump's and Republican parties' big ideas have been accommodated in the Act. Some important points from the law are; changed the corporate income tax rate from $35 \%$ to $21 \%$ and is a drastic reduction that provides a tax discount of up to $60 \%$.

Next is the change from the worldwide to a territorial system. The definition of a territorial is to provide an exemption from dividend payments originating from abroad. In this case, the

\footnotetext{
${ }^{1}$ What is meant by Worldwide Tax System is that a country will impose taxes on all income received or obtained by domestic taxpayers (WPDN) in that country, regardless of whether the income originates from within the country or abroad. In other words, if an entity is a WPDN from a country that adheres to a worldwide tax system, that entity will be taxed regardless of the source of revenue generated by the agency. In addition to imposing taxes on all income received by WPDN, countries that adhere to the worldwide tax system also impose taxes on income received by foreign taxpayers (WPLN) originating from their country.
} 
Vol.6, No.2, 2020

Doi: https://doi.org/10.24198/cosmogov.v6i2.28428 http://jurnal.unpad.ac.id/cosmogov/index

US followed the steps of Japan and the UK, which had previously changed to the territorial tax system. Corporate Income Tax, but the Law also revises the structure of Personal Income Tax (OP), primarily by lowering the highest rates and increasing the value of the income cap in the highest income groups. The revision is considered more profitable for the people in the top $20 \%$ income group and is a characteristic of Republicans leaning towards the wealthy population group. (Kristiaji, nd)

In the form of presidential like the US, they have a presidential veto power mechanism. The veto right in question is that the President clearly has a veto in the process of passing laws. The President can also use this right to reject laws that have been passed by parliament. However, the parliament can also annul the veto with the majority of the congress ( senate and house representative), about two-thirds of the parliament's vote. (Hanta Yuda, 2010) Although full of pros and cons, the tax reform law was approved by a senate filled with representatives from the Republican party. The Senate approved and provided notes of minor revisions to the then US tax bill. After a poll process, the ratification was made that resulted in 51 votes in favour and 48 votes against in 2017. The Democrat party's inputs were 1) a more detailed explanation of the new tax provision dubbed TCJA, 2) the abolition of a provision that allows parents to use 529 education savings to cover their children's school fees and 3) tax exemption from private universities. The reduction in tax rates from $35 \%$ to $21 \%$ is said to make the US compete with other industrialized countries in terms of imposing corporate tax rates. This is because the industrialized country averages a corporate tax rate of $22.5 \%$. (Andri, nd)

The portrait of the proposal, discussion and approval of the Tax Reform Law above shows some of the US bureaucracy's characteristics, namely that the bureaucracy is the dominant institution in implementing policy programs, with different levels of importance, for each stage. The bureaucracy is also not something neutral in policy choices. The author sees that the senate members, which is filled by the majority of representatives of the Republican party, will certainly agree with Trump's policies for rational reasons because they are seen as increasing the excitement of the US economy.

However, for many corporations in the US, this policy is certainly not a profitable thing. Taxes mechanism in some states in the US, causing more than 70 financial services company moved to Palm Beach County, Florida, in three years. The companies that moved the majority came from three main areas: New York, Boston and Connecticut. The three locations were affected by the imposition of state and local tax limits of US \$10,000 or approximately Rp. 142.8 million which can be deducted in federal tax returns.

The Florida area corporate tax rate is $5.5 \%$, and there is no corporate income tax on limited partnerships. Also, there is no individual tax $(\mathrm{PPh})$ in Florida. US census bureau data show that Florida has received more movements than any other state in the past year. Moving from New York to Florida could save more than the estimated US \$ 69,700 (approx. 995.7 million) in taxes per year. Palm Beach is 
Vol.6, No.2, 2020

Doi: https://doi.org/10.24198/cosmogov.v6i2.28428

http://jurnal.unpad.ac.id/cosmogov/index

also not the only Florida state that gets migrations from high-tax states, with Miami, Texas, Nevada as other states that are frequent destinations for migrations. (News, nd)

In the US, Trump's policies also impact the economies of other countries, including Indonesia. Bloomberg Economics in its report in March 2018 projected that the world economy would grow $0.5 \%$ lower in 2020 than if Trump's policies were not made. The impact is in Indonesia, existing exports may experience contraction, as a component of economic growth. The Central Bureau of Statistics (BPS) wrote that exports contributed $20.37 \%$ of the gross domestic product (GDP) structure last year (2017) with a growth of up to $9.09 \%$.

Corporations in the US have a long history, and after the mid-18th century, corporations grew and developed rapidly. By the 1920s, the company had grown and expanded so much that, in fact, scholars began to focus again on the separation of ownership and control that had been a concern for Adam Smith. They were not worried that the corporation would fail, but that the company's managers would not do the right thing by shareholders. The stock market fever spread to the masses during that giddy decade, owners of large corporations became increasingly scattered and ineffective as voices in directing management - and their managers and lawyers became increasingly adept at finding ways to keep cranky outside investors out of sight. post threats. (Fox, 2009) The market euphoria of the late 1920s and the ensuing devastation had undermined Berle from the previous idea that investment bankers or large investors might force corporate managers to do the right thing.

The corporation became so large and powerful that Berle and Means believed that competitive forces alone could not control them. They concluded that the only solution is to control the big companies to "develop into technocracy pure neutral, balancing a variety of claims by various groups in society and place each portion of the revenue stream based on public policy, instead of c updates private". (Fox, 2009)

Renowned journalist and columnist, Fox introduced a new wave of economists and scholars who no longer teaches that investors are rational or that the market is always right. Many of them now agree with Yale professor Robert Shiller that the theory of efficient markets "represents one of the most extraordinary errors in the history of economic thought." Today these theories have provided the way for opposing hypotheses about human behaviour, psychological models of decision making, and market irrationality. Investors overreact, underreact, and make irrational decisions based on imperfect data. (Fox, 2009)

The discussion of the Tax Reform Act in the US in 2017 brings a positive indication when viewed from the increase in the stock market on Wall Street. As we know, US economic indicators can be read on Wall Street and indicate how the superpower's economy is stretching. When discussing the law, Wall Street rose with three main indexes, fueled by the belief that the US tax cut policy would get enough 
Vol.6, No.2, 2020

Doi: https://doi.org/10.24198/cosmogov.v6i2.28428

http://jurnal.unpad.ac.id/cosmogov/index

support from lawmakers to pass. The Dow Jones, Nasdaq and others are reported to have strengthened, including the technology and health indices, although the energy sector is in the red and is declining. Meanwhile, the financial index rose because the Bank was seen as one of the biggest tax reform beneficiaries. (Nurmayanti, nd).

Although it brings positive indications for the rise in the stock market on Wall Street, the tax reform policy promoted by Trump and affecting existing corporations have drawn pros and cons in the US. With the Tax Reform Law's presence, it could help the US attract more companies to invest, both from within and outside the country. However, the Ernst \& Young agency said these benefits could be erased by President Donald Trump administration's trade policies. As it is known that Trump imposes high tariffs on the entry of goods from China, leading to the US-China trade war. The U.S. withdrawal from the Trans-Pacific Partnership and the South Korea-America Bilateral Free trade agreement (KORUS) occurred during the Trump administration. In the context of trade issues, Mark Weinberger as Global Director and CEO of Ernst \& Young stated that many depend on NAFTA and KORUS. The trade agreement affects existing corporate investments. According to him, withdrawing from the various trade agreements and issuing strict requirements, can reduce the incentives for companies to invest in the US, and this is of course reversed with the spirit of the Tax Reform Law. The output of tax reform benefits can only be felt when the US opens up to the world's large economies. (Natalia, nd).

The US administration's agenda that regulates the economy and corporations can also be found during the Obama administration. In 2014, Obama invited many large international companies to boost investment. At that time, he gathered executives from many international corporations, including Ford Motor Co. and Deutsche Lufthansa AG. The program initiated by the White House is called SelectUSA and has a target of attracting more than the US \$ 18 million in business investment in 17 federal states and territories. The program initiated will take advantage of the localization cycle, growth, and hiring businesses in the US. (Kusumawardhani, nd) The role of a President in recommendations and policymaking in the US is large, showing the character of the bureaucracy that reflects the power exercised by officials.

IN HIS BOOK, James Q Wilson explains that many recommendations of the President's Committee on administrative management have been adopted, but fundamental tensions remain. Formally, all the bureaus cleared their budgets and their legislative proposals with the White House; informally, the congress had no difficulty understanding which bureau chiefs were distinguished from the president in this respect. Formally, all agencies in the executive branch are under the President; informally, congress, by its powers to authorize, match and investigate, has little difficulty influencing at least the more visible activities and shaping these institutions' more operational objectives. (Wilson, 1989). 
Vol.6, No.2, 2020

Doi: https://doi.org/10.24198/cosmogov.v6i2.28428 http://jurnal.unpad.ac.id/cosmogov/index

The policy on corporate life, which Trump initiated by presenting the tax reform law, wanted to protect the US economy and help small and medium entrepreneurs in the US. However, the policies that emerged after the enactment of the Tax Reform Law are seen as policies that are not in line with the tax reform's breath. Instead of attracting foreign investors and companies to the US, Trump started a trade war with China in an economic context.

This contradictory policy shows the conception of the bureaucracy, which is said to be the official elite's power. Trump issued this policy in line with his view that China is increasingly controlling the pace of the world's economy. To that end, with the President's right of veto in making policies, Trump tried many measures to dispel the dominance of China and officially in 2017 the US pull out of trade agreements Trans-Pacific Partnership (TPP). This step is said to be moving the US away from its allies in Asia in line with China's influence in the region.

\section{Post-Policy Trump Electability}

Many policies issued by Trump have also had political implications or consequences for him. As the US President who is often said to be "quirky" and controversial, Trump is indeed full of surprises. In his book "The Making of Donald Trump" David Clay says that Donald Trump never knew his grandfather, Friedrich, who died when Donald's father Fred was only twelve years old. However, as a rogue entrepreneur, Friedrich overshadowed the Trump family for a century with his passion for money. $\mathrm{He}$ despised the good of law - such as erecting buildings on land he did not own.

Friedrich Trump grew up in the southwestern German winemaking region of the city of Kallstadt. His father had died when Friedrich was only a few years old. In 1885 , at the age of sixteen and facing conscription, Friedrich left a note to his mother and did what millions of other Europeans with little prospect of at home did: flee Germany to the United States. Enduring the North Atlantic's arduous crossing in an overcrowded steamship, Friedrich finally landed in New York, where he lived with an older sister, Katherine and her husband, who had both immigrated previously. The Friedrich Trump family tradition did start in America. However, they are a prosperous family but want more. Friedrich sold his restaurant and set up a new business about thirty miles north. (Johnston, 2016)

Fred Trump, Donald's father, was known not to establish a quality building or be a good landlord. He bought the cheapest materials to build more than 27,000 subsidized apartments and flats, many of his family continuing to collect rent decades later. As a child of Fred Trump, Donald Trump, born in 1946, is the heir to his father's business. Since 1971 he has led The Trump Organization, the main holding company for all of his property and other business interests. He has two mottoes of success, "always hit back" and "hit back harder than you hit", which came into play shortly after his father died in 1999 at the age of ninety-three. (Johnston, 2016).

Since becoming the 45th US President inaugurated in 2017, many policies issued by Trump have drawn pros 
Vol.6, No.2, 2020

Doi: https://doi.org/10.24198/cosmogov.v6i2.28428 http://jurnal.unpad.ac.id/cosmogov/index

and cons. A survey agency released data on the level of US public satisfaction with Donald Trump ahead of a year after he took office. The Gallup Survey Institute stated that the level of public satisfaction with Trump throughout 2017 only reached 39 per cent. The data makes Trump the President with the lowest level of public satisfaction in US history. This figure comes after Trump's policies which were later criticized by the public. US public doubts also occurred after the publication of a book entitled Fire and Fury: Inside the Trump White House in 2018. The book tells the audience about Trump's figure, who is impatient, unable to focus, and always babbles. However, the Gallup survey found that Trump still has a place in his Republican supporters' hearts. It was noted that 83 per cent of Republican supporters were satisfied with Trump's performance in the first year. In fact, another survey agency named Quinnipiac said that 37 per cent of US citizens expressed satisfaction with Trump for helping restore the economy. (Utomo, 2018).

Not only surveys at home but also abroad, the survey results on Trump are interesting to examine. An example is a survey conducted by YouGov, a UK-based agency with operations in Europe, North America, the Middle East and the Asia Pacific. The survey in Germany was conducted by interviewing more than 2000 people as a sample. The survey results stated that US President Donald Trump is considered a dangerous figure for the world for German citizens. In fact, he is more dangerous than other famous leaders such as Vladimir Putin and Kim Jong-un.
Respondents also saw Trump as a more dangerous figure than Iran's supreme leader, Ayatollah Ali Khamenei and Chinese President Xi Jinping. 41 per cent of respondents said Trump was the biggest threat to global peace. The institute's survey was conducted in December 2019 and involved 2,024 German citizens. (Online, 2019).

However, some people think that Donald Trump will be re-elected as President even though there are many pros and cons in his policies. This opinion poll/poll can be seen from CNN conducted by the SSRS research institute. The majority of US citizens think Donald Trump will win the 2020 presidential election again, even though he is bombarded with issues that the US economy will move negatively. 54 per cent of respondents thought Trump would win again, and 41 per cent thought he would lose.

CNN's poll results are also inversely proportional to a similar poll in December 2018, where 51 per cent of Americans expected Trump not to be reelected. The reasons for respondents who disagreed with Trump's re-election were that Trump was full of lies, racism, incompetence and did not act as president. Meanwhile, those who agree with Trump's re-election argue that they like how Trump handles his job as President, which focuses on achieving issues. A quarter of respondents voted for economic reasons, and 12 per cent for keeping promises and five per cent related to border policies. (Indonesia, 2019) On average, respondents like Trump's performance in the economic sector and migration issues are higher than 
Vol.6, No.2, 2020

Doi: https://doi.org/10.24198/cosmogov.v6i2.28428

http:/jurnal.unpad.ac.id/cosmogov/index

foreign trade policy. This poll conducted by CNN was conducted in May 2018 and used a random sample of 1,006 respondents contacted by telephone or cellphone and interviewed directly.

The US community's political electability towards Trump was increasingly seen when Joe Biden won the US Presidential Election in 2020. Based on the BBC's information, Democratic candidate Joe Biden won the US presidential election by obtaining 306 electoral college votes compared to Trump, who was a Republican candidate with 232 votes. According to the US constitution, the electoral college vote threshold for winning the presidential election competition is 270 , and Biden is way beyond that number.

The results of a survey of Trump, both from respondents who expressed their love or hatred, showed that as a leader, Trump is indeed loved and hated. Some policies he issued on the grounds of making America great again, both in the economic, trade, foreign, defence, immigration and other sectors show that the bureaucracy in a democratic system can also be seen as a "tool of power foremost for those who control the apparatus. bureaucracy". (Blau \& Meyer, 1987) It is further said that under normal conditions, the power of a developed bureaucracy is always tremendous. A "political leader will feel himself in the" weak "position as opposed to an" expert ", and face trained officials who are in the middle of government management.

\section{CONCLUSION}

The bureaucracy can be seen as a means of power for the elite in running the government. One of the phenomena seen in this bureaucratic frame is the policy towards corporations during the Donald Trump administration. Through the Tax Reform Act or known as the Tax Cut Job Action (TCJA), Trump tries to lower the tax rate which is then expected to impact the entry of investments in the US and help entrepreneurs from the middle to lower classes do business.

However, even though the congress approved this tax reform policy, the pros and cons continued to roll. Politically and economically, Trump's tax reform policy has resulted in the US-China trade war, which economists say contradicts the tax reform policy. It will make it difficult for the US to improve the economy.

Trump's economic sector policies, one of which is tax reform, have practically influenced Trump's electability. Many surveys show that respondents do not like the policies made by Trump and the Trump administration. However, some other Trump supporters also said that they liked Trump's fast performance and occupied his first campaign promise. The clear evidence of the political impact of Trump's policies during his tenure is the defeat of Trump by Joe Biden in the US Presidential election in November 2020 . The US people certainly see what Trump programs have produced regarding welfare, security, migration and foreign policy politics. 
Vol.6, No.2, 2020

Doi: https://doi.org/10.24198/cosmogov.v6i2.28428

http:/jurnal.unpad.ac.id/cosmogov/index

\section{REFERENCES}

Albrow, M. (2005). Bureaucracy. Tiara Discourse.

Andri, Y. (nd). Passed by the Senate, the US tax bill is one step closer to materializing. Bisnis.com. www.bi snis.com

Armiyati, L. (2019). New Deal; Redeveloping the United States. Deepublish.

Blau, PM, \& Meyer, MW (1987). Bureaucracy in Modern Society. UI Press.

DPR, PPBK (2018). The United StatesChina Trade War and Its Implications for Indonesia. Brief Info, $X(07), 7$.

Fox, J. (2009). The Myth of the Rational Market: A History of Risk, Reward, and Delusion on Wall Street. Harper Collins.

Gideon, A. (2014). Corporate Actions of Several Companies Raise Wall Street

Stocks. https://www.liputan6.com/ bisnis/read/2064246/aksi-

korporasi-b Several-Perusahaandongkrak-Saham-wall-street

Hanta Yuda, A.. (2010). Halfhearted Presidentialism.PT Gramedia Pustaka Utama.

Indonesia, C. (2019). CNN Poll: Majority of US Citizens Think Trump Wins Again,

2020. https://www.cnnindonesia.co $\mathrm{m} /$ internasional/20190606103227134-401317/polling-cnnmayoritas-warga-as-pikir-trumpmenang-lagi-2020

Johnston, DC (2016). The Making of Donald Trump. Melville House Printing.

Kristiaji, BB (nd). US Tax Reform: Causes and Effects. 2018. https://news.ddtc.co.id/reformasipajak-as-penyebab-dan-dampak13518 ,

Kusumawardhani, A. (nd). US Economy: Obama Will Collect Multinational Corporations. The news of business. https://kabar24.bisnis.co $\mathrm{m} / \mathrm{read} / 20140520 / 18 / 229461 / j a v a s$ cript
Milliband, R. (1973). The State in Capitalist Society. Quarter Books.

Natalia, EC (nd). Trump's Trade Policy Could Wipe Out the Benefits of Tax Reform. Cnbcindonesia. https://ww w.cnbcindonesia.com/news/20180 115110837-4-1458/keb PolicyDagang-trump-Dapat-hapuskanbenefit-reformasi-pajak,

News, RD (nd). Due to tax reasons, dozens of companies have moved to this area. Dutch News. https://news.ddtc.co.id/karenaalasan-pajak-puluhan-per company-pindah-ke-regregionalin-16654?page $\mathrm{y}=40$,

Nurmayanti. (nd). Tax Reform Policies Have a Chance to Pass Bring Wall Street Up. Coverage6. https://www.liputan6.com/bisnis/re ad/3197676/keb Policy-reformasiPajak-berpeluang-lolos-Bawawall-street-naik

Online, W. (2019). Germany: Donald Trump is more dangerous than ... news. https://www.wartaekonom i.co.id/read263448/news post.php

Orum, A. (2001). Introduction to Political Sociology. Prentice-Hall.

Postell, J. (2017). Bureaucracy in America; The Administrative State's Challenge to Constitutional Government. The University of Missouri.

Setiawan, SRD (2018). Trump Shows Off The Largest Tax Reform In US History. Kompas.Com. kompas.co $\mathrm{m}$

Utomo, AP (nd). US Public Satisfaction Rate to Trump's Lowest in History. International compass. https://internasional.kom pas.com/read/2018/01/17/1824267 1/tlasi-kepuas-publik-as-ke-trumpterendah-dalam-sejarah,

Wdi. (, 2011). Wall Street. Okezone. https://economy.o kezone.com/read/2011/09/12/226/ 501463/wall-street

Wilson, JQ (1989). Bureaucracy: What Government Agencies Do and Why They Do It. Basic Books.

Winarno, B. (2008). Public Policy Theory and Process. Medpress. 